\title{
GEOMECHANICAL EVALUATION OF THE OLÓN CLIFF FOR STABILIZATION PRE-DESIGN OF THE BLANCA ESTRELLA DEL MAR SANCTUARY, SANTA ELENA, ECUADOR
}

\author{
PAÚL CARRIÓN-MERO ${ }^{1,2}$, ROBERTH PINEDA-RUIZ ${ }^{1,2}$, MIGUEL ÁNGEL CHÁVEZ ${ }^{3}$, \\ FERNANDO MORANTE-CARBALLO ${ }^{1,4,5}$, ROBERTO BLANCO ${ }^{6}$, MARIBEL AGUILAR ${ }^{7}$ \\ \& JOSUÉ BRIONES-BITAR ${ }^{7}$ \\ ${ }^{1}$ Centro de Investigación y Proyectos Aplicados a las Ciencias de la Tierra (CIPAT-ESPOL), \\ ESPOL Polytechnic University, Ecuador \\ ${ }^{2}$ Facultad de Ingeniería Ciencias de la Tierra (FICT), ESPOL Polytechnic University, Ecuador \\ ${ }^{3}$ Independent Consultant, Expert in Geomechanics and Geology, Ecuador \\ ${ }^{4}$ Facultad de Ciencias Naturales y Matemáticas (FCNM), ESPOL Polytechnic University, Ecuador \\ ${ }^{5}$ Geo-recursos y Aplicaciones (GIGA), ESPOL Polytechnic University, Ecuador \\ ${ }^{6}$ Facultad de Geología y Minas, Instituto Superior Minero-Metalúrgico de Moa, Cuba \\ ${ }^{7}$ Junta Administradora del Sistema Regional de Agua Potable de Olón, Ecuador
}

\begin{abstract}
Olón commune has one of the quietest and safest beaches on the Ecuadorian coast, among its tourist attractions stands out the "Blanca Estrella de Mar" sanctuary, which is located on a cliff approximately $40 \mathrm{~m}$ high. This sanctuary is part of the route of the seven churches in the Santa Elena Peninsula, which is continuously visited by tourists. Nowadays, the erosion caused by the wind, added to the rain and strong waves that hit the base of the Olón cliff directly and the anthropic activities affect the slope stability, in which block detachments have already been reported, generating risk to people and the foundations of the buildings of the place. The aim of this research is to evaluate the stability of the slope by means of the geological and geomechanically characterization for the proposal of the pre-design of the stabilization measures. The methodology of this work includes four phases: (i) drone topography and systematization of information; (ii) geological and geomechanically characterization of the area; (iii) evaluation of the stability and susceptibility to slope detachment, using the classification proposed by Chen and the parameters established by the expert method respectively; and (iv) calculation of the safety factor by the Morgenstern-Price method for proposals for stabilization. According to the results obtained, the cliff has a high susceptibility to detachment, due to its inherent lithological characteristics, low cohesion, and the anthropic conditions that have developed in recent years, for this reason the predesign contemplates multiple integrated measures, using the implementation of systematic bolt and shotcrete for stabilization, control of the drainage system towards the slope, and complementary works of periodic maintenance.
\end{abstract}

Keywords: Chinese slope mass rating, instability, security factor, susceptibility, Olón cliff.

\section{INTRODUCTION}

Slope stability can be determined by analyzing geometric factors (direction, height), geological (planes or discontinuities, anisotropy on the slope), hydrogeological (presence of moisture) and geomechanical (resistance, cohesion, friction angle) which allow identification of the conditions of breakage along a surface that have generated the movement of blocks that make up the rock mass [1]. And assign a degree of stability through geomechanical classifications as for example rock mass rating (RMR) classification [2], and slope mass rating (SMR) [3], being the one of greater acceptance in works realized by the ease of his application [4], from which a series of variations to the original method are derived, obtaining the Chinese slope mass rating (CSMR) classification proposed by [5], which considers the height of the slope and the conditions presented by the discontinuities. 
This happens in all the slopes at a general level, which has generated great concern in the area of civil engineering, for this reason it is important to analyze the mechanical characteristics of the materials that make up the soil to understand their behavior and solve the problem [6].

This is the case of the Blanca Estrella del Mar Sanctuary, which is located on a $40 \mathrm{~m}$ cliff, A multi-level architectural complex that currently presents unfavorable conditions that contribute to slope wear, such as erosion due to winds and rains, a poorly located stormwater drainage system, micro-vibrations due to heavy vehicles passing by the main road and the low cohesion of the materials that form the rock mass, which has resulted in instability that affects the foundations of adjacent buildings.

Culturally and socially the location of the sanctuary has created a situation of insecurity, which requires an immediate response, and the only way to find a response threshold is to conduct an evaluation of the stability of the slope.

Analyzing the current situation presented by the escarpment, the data was recorded that in the 1970s, between the sanctuary and the edge or limit of the slope there were $10 \mathrm{~m}$, which now no longer exists. Is it possible with an evaluation of the geological, geomechanical and structural conditions, to give a proposal for a solution to the problems of instability, susceptibility, and security to the people who visit this tourist and spiritual place? Therefore, the aim of this study it is to evaluate the stability of the slope by means of the geological and geomechanically characterization for the proposal of the pre-design of the stabilization measures.

\section{GEOGRAPHICAL AND GEOLOGICAL ENVIRONMENT}

Blanca Estrella del Mar sanctuary is located in Santa Elena Province (Fig. 1), in the Olón Commune. The sanctuary is located on a slope that has a length of $245 \mathrm{~m}$ and approximately 40 with an extension of $113,000 \mathrm{~m}^{2}$.
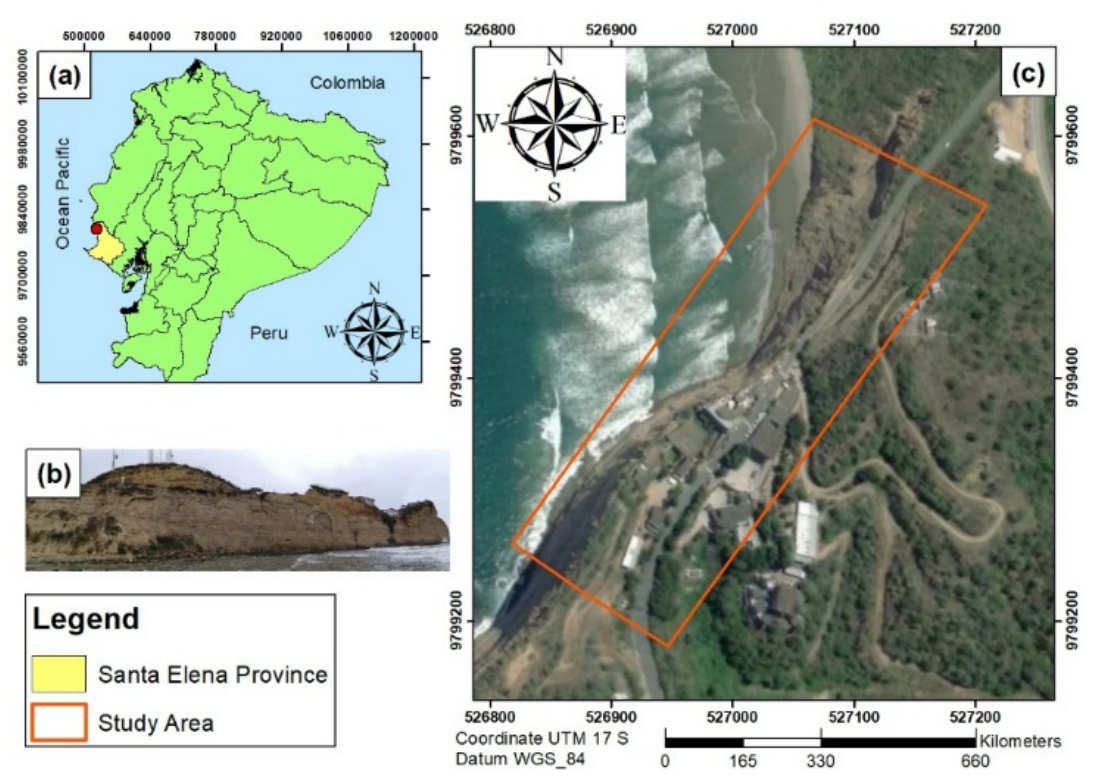

Figure 1: Location map of the study area. (a) Map of Ecuador; (b) Panoramic view of the cliff of Olón; and (c) Plan view of the study area. 
According to [7]-[9] the sedimentary fill is made up of sediments from the Ancón Group, belonging to the upper Eocene, which is made up of: Socorro Formation of Middle Eocene age, Seca Formation of the Upper Eocene, followed by the Zapotal Formation belonging to the upper Eocene and lower Oligocene and finally on the roof of the depositional sequence are the alluvial deposits (Fig. 2).

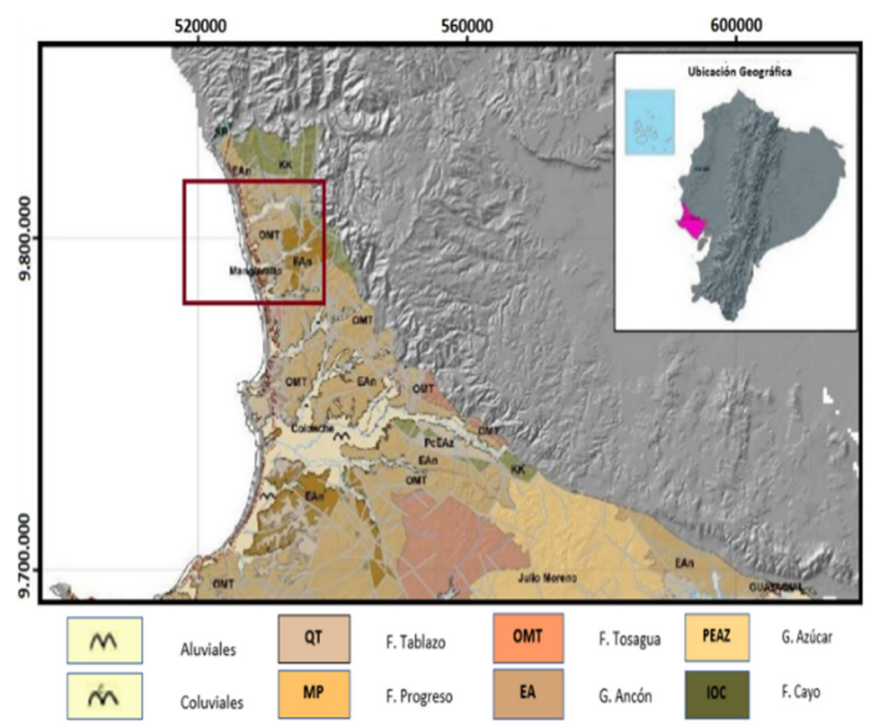

Figure 2: Geological map of the Santa Elena Peninsula [10].

\section{METHODOLOGY}

The methodology used in the development of this research consists of four phases (Fig. 3).

\subsection{Phase I: Information processing and systematization}

For the development of this research, it begins with the systematization of existing information, which is made up of scientific articles, technical reports, degree thesis and works that allow us to know the study area, the problems it faces and the field planning for the later phases.

\subsection{Phase II: Geological and geomechanical characterization}

\subsubsection{Geology}

In this phase the geological survey is carried out, which allows to know the morphology, lithology and structures present in the study area, in which structural measures of strata and discontinuities presented by the slope are taken.

In addition, strategic sites were established to perform geophysical tests that allow us to infer the type of lithology present, in areas that due to the height of the slope and the conditions it presents, it was not possible to identify: (i) Vertical Electrical Sounding (VESs) using the Schlumberger configuration; and (ii) Geoelectric Tomographs (TG) with the Wenner configuration, with horizontal distances of $200 \mathrm{~m}$, whose results will be resistance and resistivity values respectively. 


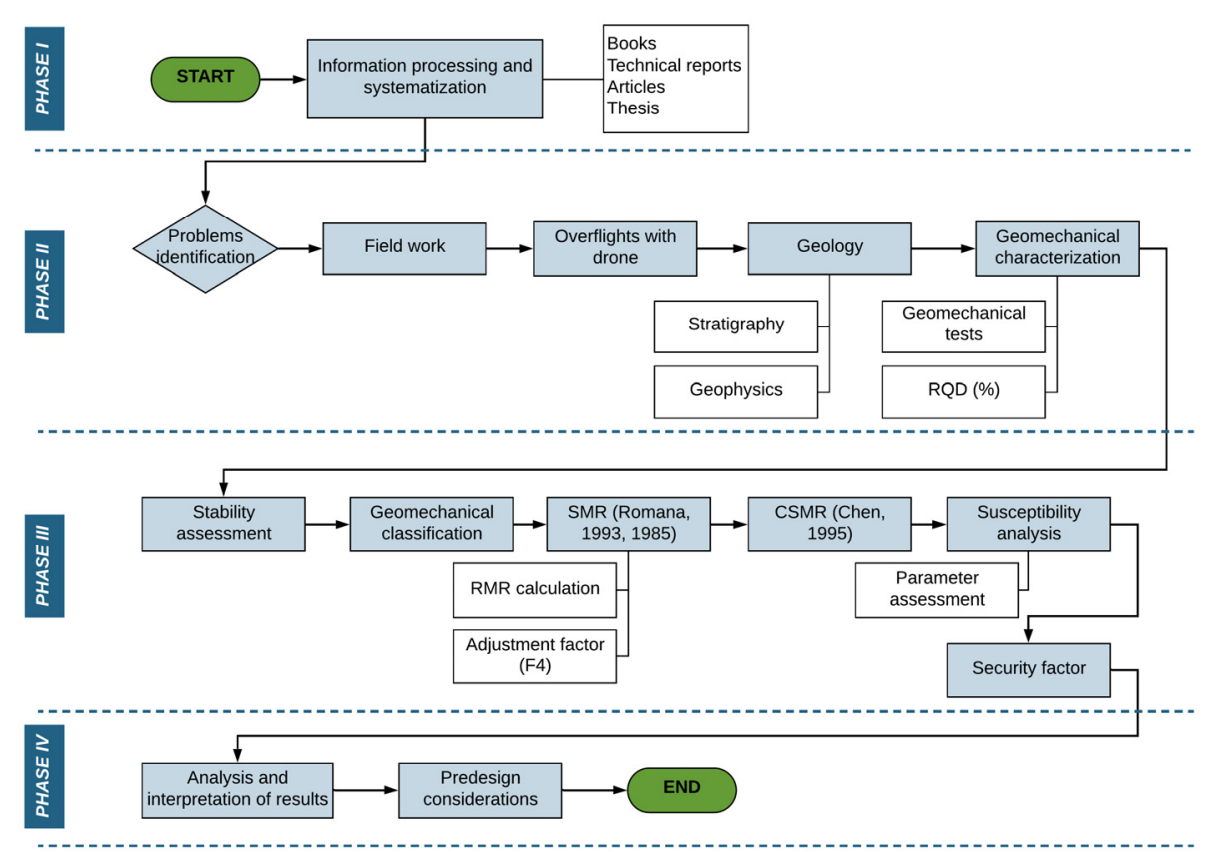

Figure 3: Flowchart of the methodology to follow for the development of this study.

\subsubsection{Geomechanical characterization}

Considering the height of the slope, its location and conditions, a three-dimensional model was made, with the help of images with resolution (20 MP), captured with Drone (Phanton 4 Pro) and its "Flight System" (Figs 4 and 5). This model allows us to obtain the topography of the sector, as well as the identification and measurement of fractures present. To perform the geomechanical characterization, the slope has been divided into two zones considering its change of direction and diving, each zone is divided into sectors based on the conditions that present (presence of water, load, vegetation cover). Finally, a sampling of the different types of rock is performed to perform geomechanical tests and subsequently obtain the rock quality designation (RQD) index (\%).

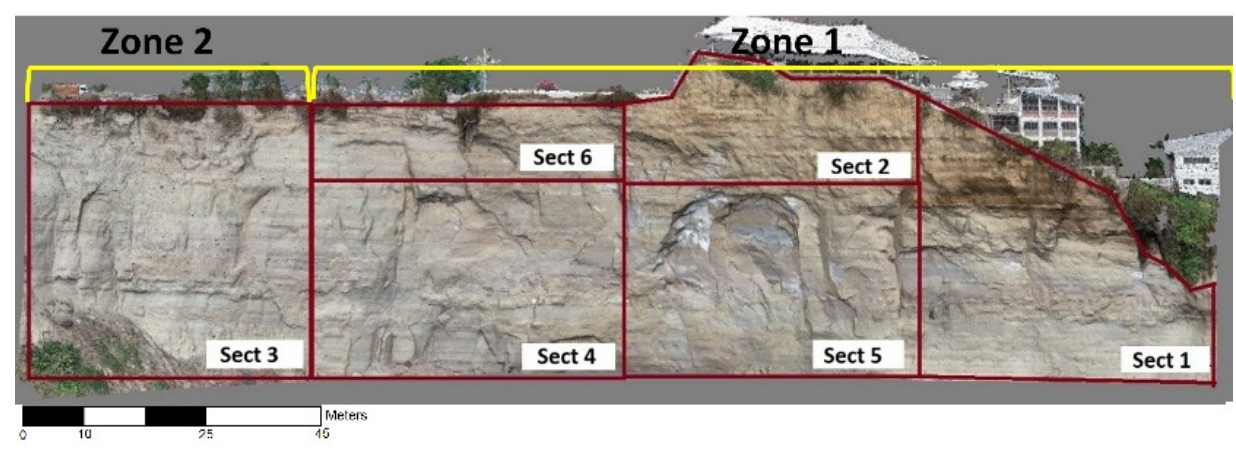

Figure 4: Subdivision of the three-dimensional model of the slope into zones and sectors. 


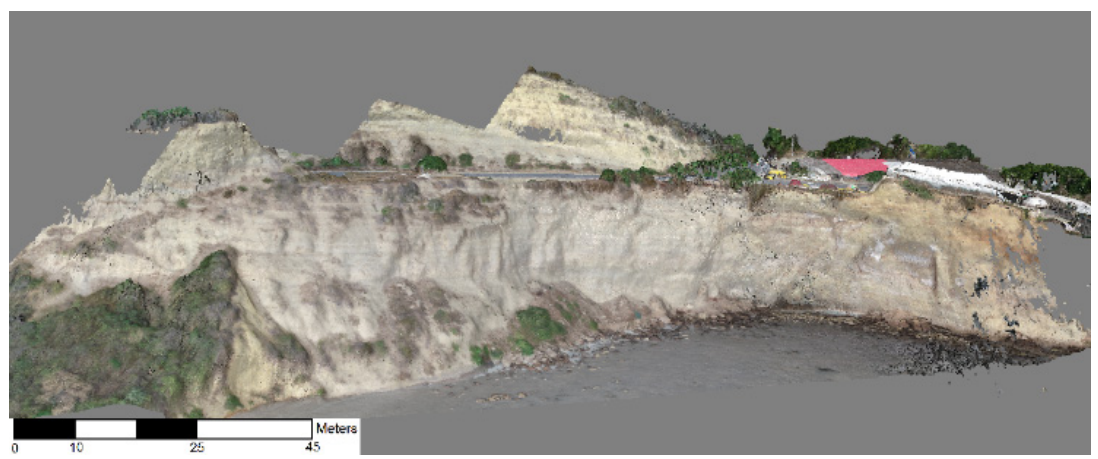

Figure 5: Front view of the three-dimensional model of the cliff.

\subsubsection{Rock quality designation (RQD)}

Was defined by Deere and Deere [11], it was used as a classification for rock mass stability. The RQD allows to obtain the quality of a rock mass and can be determined from the sampling of the exploration line, in intact sections of more than $10 \mathrm{~cm}$. This method considers the spacing between fractures; for this reason, Priest and Hudson [12], proposes eqn (1) and [11] proposed a quantitative rating (Table 1)

$$
\mathrm{RQD}=100 \times \mathrm{e}-0.1 \lambda \times(0.1 \lambda+1),
$$

where $\lambda$ is the number of fractures per meter.

Table 1: RQD (\%) quantitative rating [11].

\begin{tabular}{|c|c|c|}
\hline \multicolumn{3}{|c|}{ Rock quality designation (RQD) } \\
\hline A & $0-25$ & Very poor \\
\hline B & $25-50$ & Poor \\
\hline C & $50-75$ & Fair \\
\hline D & $75-90$ & Good \\
\hline E & $90-100$ & Very good \\
\hline
\end{tabular}

3.3 Phase III: Evaluation of the stability and detachment susceptibility

\subsubsection{Geomechanical classification}

The stability conditions presented by the slope were evaluated by means of the CSMR classification which considers the SMR classification.

\subsubsection{Slope mass rating (SMR)}

To determine the SMR (eqn (2)), a basic RMR index is added, which changes between 0 and 100 (Table 2) an adjustment factor, joint orientation (eqn (3)), the product of these three factors $(\mathrm{F} 1 \mathrm{xF} 2 \mathrm{xF} 3)$ and a digging factor [13] (Table 3)

$$
\mathrm{SMR}=\mathrm{RMR}+(\mathrm{F} 1 \times \mathrm{F} 2 \times \mathrm{F} 3)+\mathrm{F} 4 .
$$

F1: It is determined by the degree of parallelism between the strike of the discontinuities and the strike of the slope. It is calculated using eqn (3) 


$$
\mathrm{F} 1=(1-\operatorname{sen}|\alpha \mathrm{j}-\alpha \mathrm{s}|)^{2},
$$

where $\alpha j$ and $\alpha$ s are the direction of dip of the joints and slope direction respectively.

F2: It depends on the discontinuity dip in the case of planar failure and the plunge (eqn (4))

$$
\mathrm{F} 2=\operatorname{tg}^{2}(\beta \mathrm{j})
$$

where $\beta \mathrm{j}$ It is the joint dip.

F3: Represents the relationship between the dip of the joint and the dip of the slope.

F4: It depends on the excavation method used.

\begin{tabular}{|c|c|c|c|c|c|c|c|}
\hline Parameter & \multicolumn{7}{|c|}{ Ratings } \\
\hline \multirow{3}{*}{$\begin{array}{l}\text { Simple } \\
\text { compressive } \\
\text { strength } \\
(\mathrm{MPa})\end{array}$} & \multirow{2}{*}{$>250$} & \multirow{2}{*}{$250-100$} & \multirow{2}{*}{$100-50$} & \multirow{2}{*}{$50-25$} & \multicolumn{3}{|c|}{$<25$} \\
\hline & & & & & $25-5$ & $5-1$ & $<1$ \\
\hline & 15 & 12 & 7 & 4 & 2 & 1 & 0 \\
\hline \multirow{2}{*}{ RQD (\%) } & $100-90$ & $90-75$ & $75-50$ & $50-25$ & \multicolumn{3}{|c|}{$<25$} \\
\hline & 20 & 17 & 13 & 6 & \multicolumn{3}{|c|}{3} \\
\hline \multirow{2}{*}{$\begin{array}{l}\text { Separation } \\
\text { between } \\
\text { join }(\mathrm{mm})\end{array}$} & $>2000$ & $2000-600$ & $600-200$ & $200-60$ & \multicolumn{3}{|c|}{$<60$} \\
\hline & 20 & 15 & 10 & 8 & \multicolumn{3}{|c|}{5} \\
\hline \multirow{2}{*}{$\begin{array}{l}\text { Disc. } \\
\text { Length (m) }\end{array}$} & $\begin{array}{l}\mathrm{L}<1 \\
(\mathrm{~m}) \\
\end{array}$ & $\begin{array}{c}1<\mathrm{L}<3 \\
(\mathrm{~m})\end{array}$ & $\begin{array}{c}3<\mathrm{L}<10 \\
(\mathrm{~m})\end{array}$ & $\begin{array}{c}10<\mathrm{L}<20 \\
(\mathrm{~m})\end{array}$ & \multicolumn{3}{|c|}{$\mathrm{L}>20(\mathrm{~m})$} \\
\hline & 6 & 4 & 2 & 1 & \multicolumn{3}{|c|}{0} \\
\hline \multirow[t]{2}{*}{ Roughness } & $\begin{array}{l}\text { Very } \\
\text { rough }\end{array}$ & Rough & $\begin{array}{l}\text { Slightly } \\
\text { rough }\end{array}$ & Wavy & \multicolumn{3}{|c|}{ Soft } \\
\hline & 6 & 5 & 3 & 1 & \multicolumn{3}{|c|}{0} \\
\hline \multirow[t]{2}{*}{ Gap (mm) } & Closed & $\begin{array}{l}\text { Separation } \\
<1 \mathrm{~mm} \\
\end{array}$ & $\begin{array}{l}\text { Separation } \\
0.1-1 \mathrm{~mm} \\
\end{array}$ & $\begin{array}{c}\text { Separation } \\
1-5 \mathrm{~mm} \\
\end{array}$ & \multicolumn{3}{|c|}{$\begin{array}{l}\text { Separation } \\
>5 \mathrm{~mm}\end{array}$} \\
\hline & 6 & 5 & 3 & 1 & \multicolumn{3}{|c|}{0} \\
\hline \multirow[t]{2}{*}{ Filler (mm) } & None & $\begin{array}{l}\text { Hard-filled } \\
<5 \mathrm{~mm}\end{array}$ & $\begin{array}{l}\text { Hard-filled } \\
>5 \mathrm{~mm}\end{array}$ & $\begin{array}{l}\text { Soft-filled } \\
<5 \mathrm{~mm}\end{array}$ & \multicolumn{3}{|c|}{$\begin{array}{l}\text { Soft-filled } \\
>5 \mathrm{~mm}\end{array}$} \\
\hline & 6 & 5 & 3 & 1 & \multicolumn{3}{|c|}{0} \\
\hline \multirow[t]{2}{*}{ Edges status } & $\begin{array}{c}\text { Healthy } \\
\text { edges }\end{array}$ & $\begin{array}{l}\text { Little edges } \\
\text { weathered }\end{array}$ & $\begin{array}{c}\text { Medium } \\
\text { weathered } \\
\text { edges }\end{array}$ & $\begin{array}{c}\text { Heavily } \\
\text { weathered } \\
\text { edges } \\
\end{array}$ & \multicolumn{3}{|c|}{ Decomposed } \\
\hline & 6 & 5 & 3 & 1 & \multicolumn{3}{|c|}{0} \\
\hline Score & 30 & 24 & 14 & 5 & \multicolumn{3}{|c|}{0} \\
\hline \multirow{2}{*}{$\begin{array}{l}\text { Water flow } \\
\text { in the joints }\end{array}$} & $\begin{array}{c}\text { Dry } \\
0\end{array}$ & $\begin{array}{l}\text { Slightly damp } \\
\quad(0-0.1)\end{array}$ & $\begin{array}{c}\text { Damp } \\
(0.1-0.2) \\
\end{array}$ & $\begin{array}{c}\text { Drips } \\
(0.2-0.5) \\
\end{array}$ & \multicolumn{3}{|c|}{$\begin{array}{l}\text { Flow } \\
-0.5\end{array}$} \\
\hline & 15 & 10 & 7 & 4 & \multicolumn{3}{|c|}{0} \\
\hline
\end{tabular}

Table 2: Ratings to obtain the RMR index [2]. 
Table 3: Adjustment factors of the SMR classification [3].

\begin{tabular}{|l|c|c|c|c|c|}
\hline \multirow{3}{*}{ Adjustment factors } & \multicolumn{5}{|c|}{$\alpha$ = Slope direction; $\beta \mathrm{j}=$ Dip of the joints; } \\
\cline { 2 - 6 } & $\begin{array}{c}\text { Very } \\
\text { favorable }\end{array}$ & Favorable & Fair & Unfavorable & $\begin{array}{c}\text { Very } \\
\text { unfavorable }\end{array}$ \\
\hline Flat break $|\alpha \mathrm{j}-\alpha \mathrm{s}|$ & $>30^{\circ}$ & $30-20^{\circ}$ & $20-10^{\circ}$ & $10-5^{\circ}$ & $<5^{\circ}$ \\
\hline Tip over $\beta \mathrm{j}-\beta \mathrm{s}-180^{\circ}$ & 0.15 & 0.40 & 0.70 & 0.85 & 1.00 \\
\hline Flat break & $<20^{\circ}$ & $20-30^{\circ}$ & $30-35^{\circ}$ & $35-45^{\circ}$ & $>45^{\circ}$ \\
\cline { 2 - 7 } & 0.15 & 0.40 & 0.70 & 0.85 & 1.00 \\
\hline Tip over & $>10^{\circ}$ & $10-0^{\circ}$ & $0^{\circ}$ & $0-10^{\circ}$ & $<-10^{\circ}$ \\
\hline Flat break & $<110^{\circ}$ & $110-120^{\circ}$ & $>120^{\circ}$ & - & - \\
\hline Tip over & 0 & -6 & -25 & -50 & -60 \\
\hline Score & $\begin{array}{c}\text { Natural } \\
\text { slope }\end{array}$ & Precut & $\begin{array}{c}\text { Soft } \\
\text { blasting }\end{array}$ & $\begin{array}{c}\text { Blasting or } \\
\text { mechanic }\end{array}$ & $\begin{array}{c}\text { Poor } \\
\text { blasting }\end{array}$ \\
\hline \multirow{2}{*}{ Excavation method } & +15 & +10 & +8 & 0 & -8 \\
\hline SMR & $100-81$ & $80-61$ & $60-41$ & $40-21$ & $20-0$ \\
\hline Description & Very good & Good & Normal & Bad & Very bad \\
\hline Degree of stability & $\begin{array}{c}\text { Fully } \\
\text { stable }\end{array}$ & Stable & $\begin{array}{c}\text { Partially } \\
\text { unstable }\end{array}$ & Unstable & $\begin{array}{c}\text { Totally } \\
\text { unstable }\end{array}$ \\
\hline
\end{tabular}

\subsubsection{Chinese slope mass rating (CSMR)}

The classification proposed by [5], it is a variation to the conventional SMR method. And it adds two coefficients $(\zeta$ and $\lambda$ ) to eqn (5)

$$
\mathrm{CSMR}=(\zeta \times \mathrm{RMR})-(\lambda \times \mathrm{F} 1 \times \mathrm{F} 2 \times \mathrm{F} 3)+\mathrm{F} 4,
$$

where $\zeta$ is the height and according to [14], is calculated using eqn (6)

$$
\zeta=0.57+(0.43 \times 80 / H),
$$

where $\lambda$ is the factor that represents the conditions presented by discontinuities and varies between 0.7 and 1.0 (Table 4 ).

Table 4: Values of $\lambda$ for discontinuities [5].

\begin{tabular}{|l|c|}
\hline Conditions of discontinuities & $(\lambda)$ \\
\hline Joints and stratification planes closely linked & 0.7 \\
\hline Stratification plans, large-scale joints with presence of water & $0.9-0.8$ \\
\hline Faults, long and weak joints filled with clays & 1.0 \\
\hline
\end{tabular}

3.3.4 Detachment susceptibility analysis

According to the methodology proposed by experts [15]-[18] which consider eight parameters with different ratings (Table 5).

Once the susceptibility has been evaluated according to the assessment for each of the main parameters and according to the classification proposed by [19], modified by [17] and used in the geomechanical evaluation of [20], which allows us to assign a category to the type of susceptibility from very high to very low, as shown in Table 6. 
Table 5: Scores assigned to each main parameter [15]-[17], [20].

\begin{tabular}{|l|c|}
\hline Main parameter & $\begin{array}{c}\text { Maximum assessment for the analysis } \\
\text { of susceptibility to detachment }\end{array}$ \\
\hline Geological structure & Up to 4.0 \\
\hline Vegetation presence & Up to 4.0 \\
\hline Lithology & Up to 4.0 \\
\hline Seismic activity & Up to 4.0 \\
\hline State of deterioration & Up to 4.0 \\
\hline Morphometry and height & Up to 6.0 \\
\hline Degree of fracturing and key blocks & Up to 6.0 \\
\hline Water evidence & Up to 6.0 \\
\hline
\end{tabular}

Table 6: Classification of susceptibility [20].

\begin{tabular}{|l|l|c|}
\hline Susceptibility category & Observation & Category \\
\hline $\begin{array}{l}\text { Very low susceptibility: } \\
\text { SD }<8.0\end{array}$ & Stable conditions & I \\
\hline $\begin{array}{l}\text { Low susceptibility: } \\
\text { SD }(8-15)\end{array}$ & Stable conditions, with proper monitoring & II \\
\hline $\begin{array}{l}\text { Medium susceptibility: } \\
\text { SD (15-21) }\end{array}$ & Partially conditions stable & III \\
\hline $\begin{array}{l}\text { High susceptibility: } \\
\text { SD (21-28) }\end{array}$ & $\begin{array}{l}\text { Conditions potentially unstable, favor the } \\
\text { detachment }\end{array}$ & IV \\
\hline $\begin{array}{l}\text { Very high susceptibility: } \\
\text { SD }>28\end{array}$ & Very unstable conditions that favor detachment & V \\
\hline
\end{tabular}

For the susceptibility analysis it will be analyzed in current conditions that the escarpment presents, in relation to extreme conditions in which a high degree of rainfall and high seismic activity is considered.

\subsubsection{Safety factor}

For the calculation of the safety factor, five topographic profiles (Fig. 6) and the geomechanical properties of the materials were used, using the method proposed by [21], considering the lowest factor for the analysis and considerations for the stabilization predesign.

\section{RESULTS}

\subsection{Geological characterization}

Through the information collected in the field, the stratigraphy presented by the escarpment was identified based on the description of lithics ranging from fine to medium grain sandstone with dark to light brown clasts, presence of whitish limestone weathering; to saturated shale with a high degree of fracturing, located in the sector with the highest fracture of the slope. The stratification has a general diving direction of $\mathrm{N} 174^{\circ}$ and a diving direction of approximately $16^{\circ}$. The slope consists of five units which add a total power of $39 \mathrm{~m}$ (Fig. 7). 


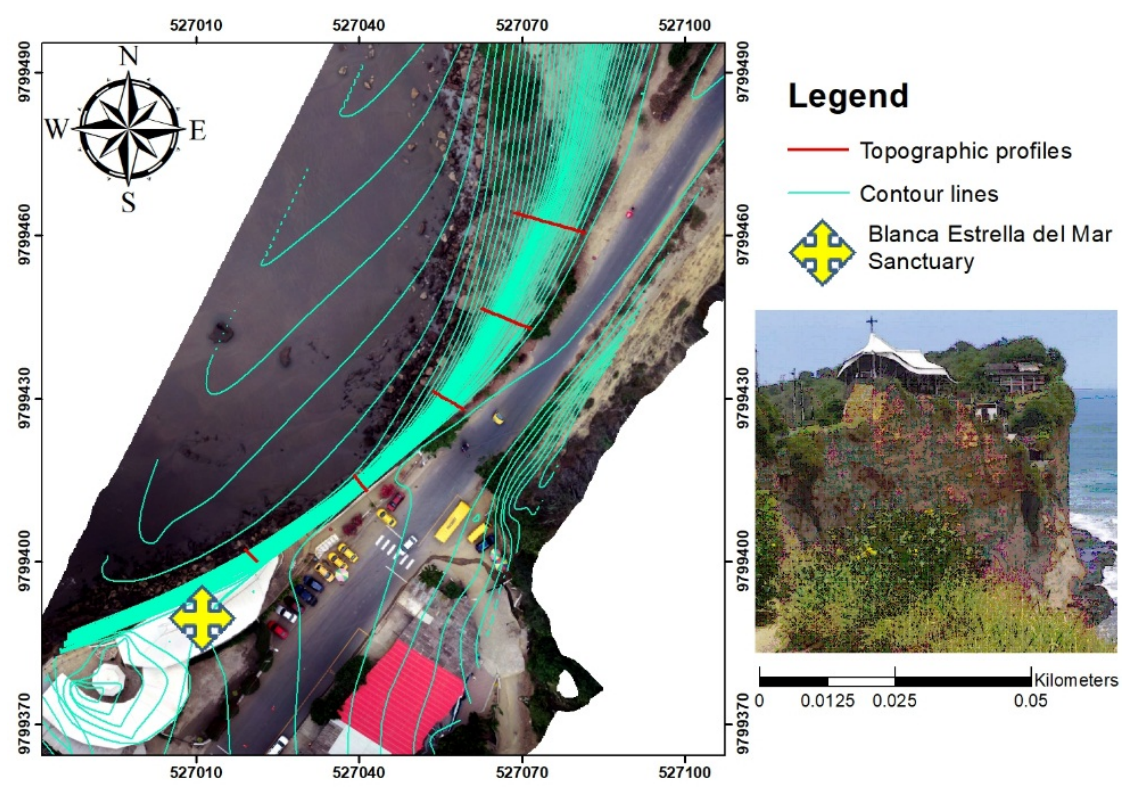

Figure 6: Location of topographic profiles along the slope.

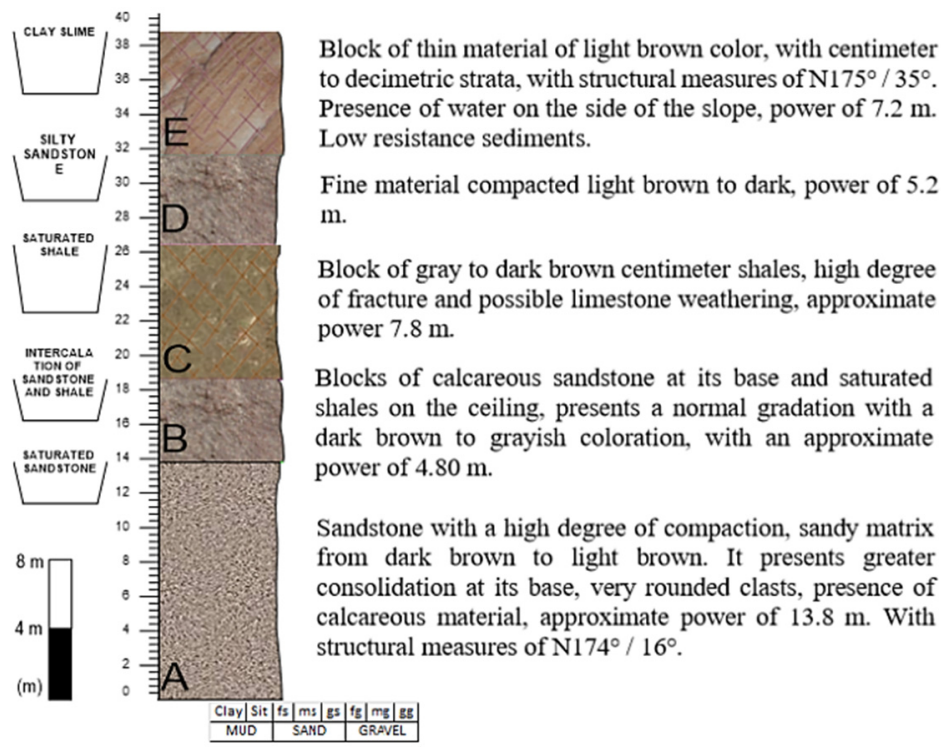

Figure 7: Stratigraphic column of the Olón cliff.

\subsection{Geomechanical characterization}

\subsubsection{Physical-mechanical properties}

The results obtained in the ESPOL Soil Laboratory are detailed in Table 7. 
Table 7: Geomechanical properties of the samples obtained in the field.

\begin{tabular}{|c|l|c|c|c|c|}
\hline No. & Rock type & $\begin{array}{c}\text { Specific weight } \\
\left(\mathrm{KN} / \mathrm{m}^{3}\right)\end{array}$ & $\begin{array}{c}\text { Compression } \\
\text { resistance }(\mathrm{MPa})\end{array}$ & $\begin{array}{c}\text { Cohesion } \\
(\mathrm{MPa})\end{array}$ & $\begin{array}{c}\text { Friction } \\
\text { angle }\left({ }^{\circ}\right)\end{array}$ \\
\hline 1 & Sandstone & 18.22 & 13.2 & 5.2 & 37.1 \\
\hline 2 & Shale & 2.17 & 10 & 3.65 & 30.5 \\
\hline 3 & Clay slime & 18.03 & 12.3 & 6.05 & 39 \\
\hline 4 & Silty sandstone & 18 & 13 & 5.52 & 37.9 \\
\hline
\end{tabular}

\subsection{RQD, SMR and CSMR}

RQD indicates an average quality for sectors 1, 2 and 6, and good for the remaining sectors. The results obtained from the stability assessment for the RMR, SMR and CSMR classifications are presented in Table 8 .

Table 8: Results obtained from the stability evaluation.

\begin{tabular}{|c|c|c|c|c|c|c|c|c|c|}
\hline \multirow{2}{*}{ Zone } & \multirow{2}{*}{ Sector } & \multirow{2}{*}{$\begin{array}{c}\text { RQD } \\
(\%)\end{array}$} & \multirow{2}{*}{ Quality } & \multirow{2}{*}{ RMR } & \multirow{2}{*}{ SMR } & \multirow{2}{*}{ CSMR } & \multicolumn{3}{|c|}{ Quality } \\
\hline & & & & & & & RMR & SMR & CSMR \\
\hline \multirow{5}{*}{$\begin{array}{c}\text { Zone } \\
1\end{array}$} & 1 & 51.75 & Fair & 38 & 50.2 & 55.52 & Low & Low & Fair \\
\hline & 2 & 58.42 & Fair & 41 & 53.2 & 54.34 & Fair & Fair & Fair \\
\hline & 4 & 62.85 & Fai & 45 & 57.2 & 34.20 & Fair & Fair & Low \\
\hline & 5 & 53.63 & Fai & 42 & 54.2 & 31.20 & Fair & Fair & Low \\
\hline & 6 & 60.93 & Fair & 62 & 74.2 & 51.20 & Good & Good & Fair \\
\hline $\begin{array}{c}\text { Zone } \\
2\end{array}$ & 3 & 74.83 & Good & 43 & 56.45 & 32.20 & Fair & Fair & Low \\
\hline
\end{tabular}

\subsection{Detachment susceptibility evaluation}

\subsubsection{Normal and extreme conditions}

In normal conditions we obtained that a very high susceptibility was obtained for sectors 3 and 5 (Fig. 8) while in extreme conditions a very high susceptibility was obtained for all sectors, except sector 2 .

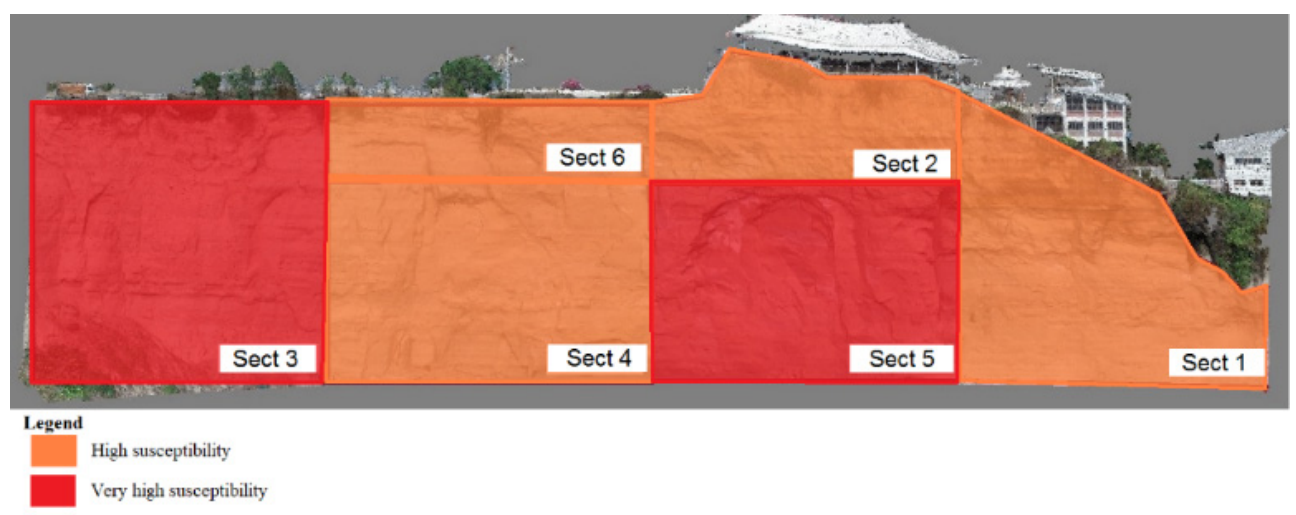

Figure 8: Detachment susceptibility evaluation to normal conditions. 


\subsection{Security factor}

Table 9 shows a summary of the results of susceptibility obtained for each sector under current and extreme conditions in relation to the real and hypothetical safety factor, considering the surface that tends to suffer a block detachment. Fig. 9 shows the lowest result of safety factor obtained in profile 1 (zone 2 ).

Table 9: Safety and susceptibility factors according to the slope area.

\begin{tabular}{|c|c|c|c|c|c|c|}
\hline Zone & Sector & Profile & $\begin{array}{c}\text { Susceptibility: } \\
\text { Actual } \\
\text { conditions }\end{array}$ & $\begin{array}{c}\text { Susceptibility: } \\
\text { Extreme } \\
\text { conditions }\end{array}$ & $\begin{array}{l}\text { (F.S) } \\
\text { Hypothetical }\end{array}$ & $\begin{array}{l}\text { (F.S) } \\
\text { Real }\end{array}$ \\
\hline \multirow{5}{*}{ Zone 1} & 1 & \multirow{5}{*}{$\begin{array}{l}5 \\
3 \\
4\end{array}$} & High & Very high & \multirow{5}{*}{$\begin{array}{l}0.591 \\
0.537 \\
0.562\end{array}$} & \multirow{5}{*}{$\begin{array}{l}0.936 \\
0.930 \\
0.933\end{array}$} \\
\hline & 2 & & High & High & & \\
\hline & 4 & & High & Very high & & \\
\hline & 5 & & Very high & Very high & & \\
\hline & 6 & & High & Very high & & \\
\hline \multirow{2}{*}{ Zone 2} & \multirow{2}{*}{3} & 1 & \multirow{2}{*}{ Very high } & \multirow{2}{*}{ Very high } & 0.469 & 0.907 \\
\hline & & 2 & & & 0.447 & 0.936 \\
\hline
\end{tabular}
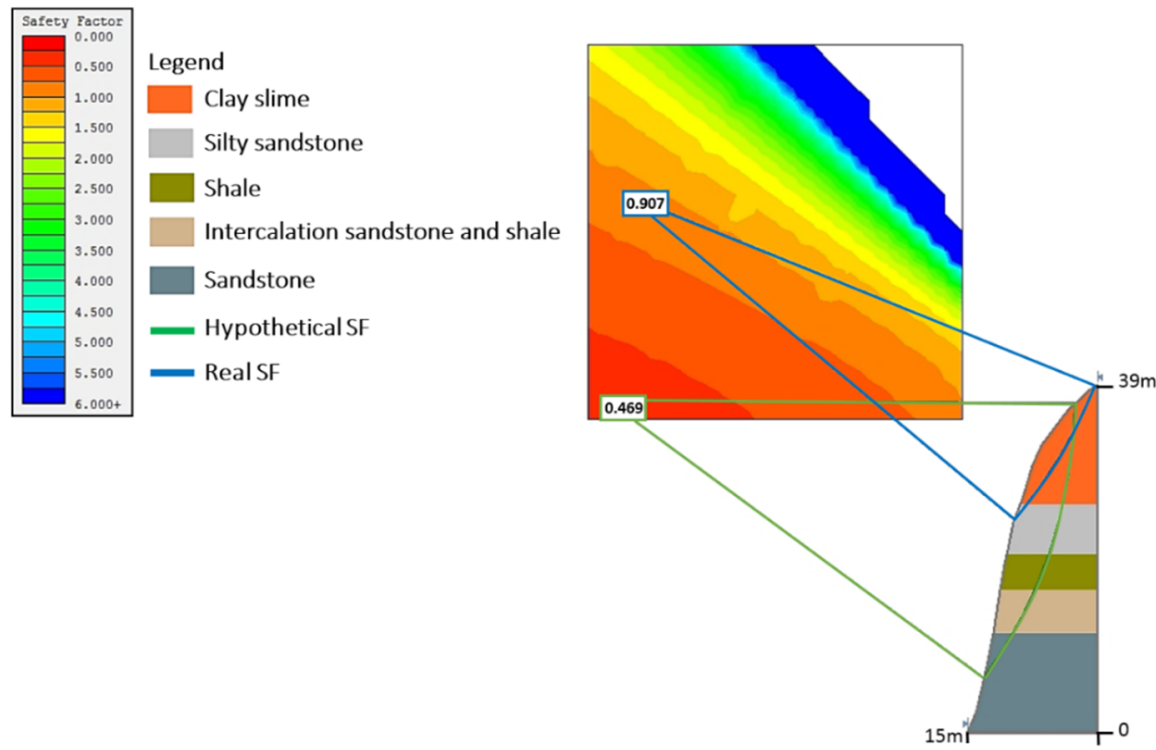

Figure 9: Safety factor obtained for zone.

\section{ANALYSIS AND INTERPRETATION OF RESULTS}

The results obtained from the geological characterization and geophysical tests allow us to associate the lithic to the Ancón Group, consisting of sandstones, calcareous shales, silts and clays, according to [7]-[9].

The strike presented by fractures, discontinuities, spherical weathering and the strata of the massif favor the detachment of large blocks in the form of breakage due to overturning. 
The results obtained for the RQD (\%), RMR, SMR, keep a similar degree of relationship, which allows us to verify with the degree of susceptibility obtained. Sectors 2, 4 and 5 have a medium quality in relation to sectors 1 and 3, which have low quality. On the other hand, the CSMR indicates that sectors 3, 4 and 5 have a low quality, considering the height of the escarpment and the state of the discontinuities.

By analyzing the compilation of methods proposed by [15]-[18] who conducted an evaluation of conditioning factors and triggers, which allow obtaining the degree of susceptibility, a very high susceptibility was determined for sectors 1, 2, 4 and 6 under current conditions. These values match the lowest real safety factor value obtained (0.907), which indicates instability conditions according to Melentijevic [22].

\section{CONCLUSIONS}

The geological characterization indicates the presence of materials associated with resistivities of sedimentary lithics of fine to medium grains, possibly saturated and high degree of weathering and compaction. The slope consists of five units having at its base medium grain sandstone with evidence of erosion, followed by an intercalation of calcareous sandstone and shale with a fine to medium granulometry, underlies a very fractured fine grain shale unit. Next, we have a block of silty sandstone with fine to medium grains and finally the clay silt unit consisting of fine grains and presence of water weathering due to the rainwater drainage system located next to the slope.

The RMR index varies between 38 and 45 with a quality that goes from low to medium, with a higher presence of medium quality in sectors $2,3,4$ and 5 and low in sector 1 . These values are corroborated with the results of the SMR, which has a range of 50.2 and 57.2 of medium category, where sectors 2, 3, 4 and 5 have a medium and low quality in sector 1 . For the CSMR classification, values between 31.2 and 55.5 were obtained representing conditions Low to normal.

The safety factors obtained for the 6 profiles chosen to indicate that the most critical value was 0.907 , this value is related to the degree of susceptibility obtained for each sector, generating confidence in the results previously obtained.

\section{RECOMMENDATIONS}

Based on the geomechanical properties and the conditioning and triggering factors that favor the instability of the slope studied, it is recommended to determine a stabilization plan that includes anchors distributed uniformly with an angle of $30^{\circ}$ from the horizontal considering the subhorizontal dip of the strata with a shotcrete layer that acts as a stabilized front finish. In addition, a drainage system that allows the discharge of rainwater into the slope should be implemented.

\section{ACKNOWLEDGEMENTS}

Our thanks go to the ESPOL Polytechnic University research project "Registro de patrimonio geológico y minero y su incidencia en la defensa y preservación de la geodiversidad en el Ecuador", the UVS project "Gestión integral del agua en cuencas hidrográficas de la Parroquia Manglaralto", engineer Andrés Sanchez for the services provided for the use of the drone, and to the Santa María del Fiat Foundation for the collaboration provided in the research.

\section{REFERENCES}

[1] González de Vallejo, L., Ingeniería Geológica, Pearson: Madrid, 2002. 
[2] Bieniawski, Z.T., Engineering Rock Mass Classifications: A Complete Manual for Engineers and Geologists in Mining, Civil and Petroleum Engineering, John Wiley: New York, 1989.

[3] Romana, M., New adjustment ratings for application of BIENIAWSKI classification to slopes. Int. Symp. on the Role of Rock Mechanics ISRM, pp. 49-53, 1985.

[4] Tomás, R., Romana, M. \& Serón, J.B., Revisión del estado actual de la clasificación geomecánica Slope Mass Rating (SMR), Ingeniería Civil, 190, pp. 53-60, 2017.

[5] Chen, Z., Recent developments in slope stability análisis. Tokyo: International Society for Rock Mechanics and Rock Engineering, 8th ISRM Congress, pp. 1041-1048, 1995.

[6] Moreno-Alcívar, L., Muñoz-Rosado, M. \& Ramírez-Palma, R., Caracterización Mecánica de Suelos del Perfil Costero entre Ancón y Anconcito. Ciencia UNEMI, 12(31), pp. 40-53, 2019.

[7] Valencia, J., Análisis Hidrogeológico de la Cuenca del Río Manglaralto para la caracterización de sus Sistemas Acuíferos, Escuela Superior Politécnica del Litoral: Guayaquil, pp. 90-92, 2017.

[8] Núñez del Arco, E., Geología del Ecuador, Profesor de la Facultad de Ingenierías en Ciencias de la Tierra, Escuela Superior Politécnica del Litoral: Guayaquil, 2003.

[9] Bristow, C.R., \& Hoffstetter, R., Lexique Stratigraphieque International, Centre National de la Recherche Scientifique: Paris, 1977.

[10] INAMHI, Introducción a la Hidrogeología del Ecuador, Quito, 2015.

[11] Deere, D.U. \& Deere, D.W., The Rock Quality Designation (RQD) Index in Practice, Classification Systems for Engineering Purposes, ASTM STP 984, pp. 91-101, 1988.

[12] Priest, S.D. \& Hudson, J.A., Discontinuity spacings in rock. International Journal of Rock Mechanics and Mining Sciences and Geomechanics Abstracts, pp. 135-148, 1976.

[13] Romana, M., Serón J. \& Montalar, E., La clasificación geomecánica SMR: Aplicación, Experiencias y validación, de V Simposio Nacional sobre Taludes y Laderas: Madrid, 2001.

[14] Basahel, H. \& Mitri, H., Application of rock mass classification systems to rock slope stability assessment: A case study. Journal of Rock Mechanics and Geotechnical Engineering, pp. 993-1009, 2017.

[15] Anbalagan, R., Landslide Hazard Evaluation and Zonation Mapping in Mountainous Terrain, Elsevier Science Publishers, pp. 269-277, 1992.

[16] Suarez, J., Deslizamientos y Estabialidad de Taludes en Zonas Tropicales, Publicaciones UIS, 1998.

[17] Blanco, R., Estudios y Propuestas de Estabilización del Cerro Las Cabras, CIPATESPOL: Guayaquil, 2015.

[18] Nicholson, D. \& Hencher, S., Assessing the potential for deterioration of engineered rockslopes. Engineering Geology and the Environment, eds P. Marinos, G. Koukis, G. Tsiambaos \& C. Stournaras, pp. 911-917, 1997.

[19] Mora, R., Aplicación de la metodología MVM para determinar la susceptibilidad a deslizamientos, Escuela Centroamericana de Geología, 2004.

[20] Aguilar, M. \& Ramírez, G., Studio Geológico, geomecánico y su incidencia en la evaluación de la estabilidad del talud del Cementerio Patrimonial General (Puerta 1) Cerro del Carmen, Guayaquil, ESPOL-CIPAT: Guayaquil, 2018.

[21] Morgenstern, N. \& Price, V., The Analysis of the Stability of General Slip Surfaces, The Institution of Civil Engineers: London, 1965.

[22] Melentijevic, S., Estabilidad de taludes en macizos rocosos con criterios de rotura no lineales y leyes de fluencia no asociada, Madrid, 2005. 